\title{
Elevated recombinant clyA gene expression in the uropathogenic Escherichia coli strain 536, a clue to explain pathoadaptive mutations in a subset of extraintestinal $E$. coli strains
}

Constance Oben Ayuk Enow ${ }^{1}$, Jan Oscarsson ${ }^{1,2}$, Nikola Zlatkov", Marie Westermark, Marylise Duperthuy ${ }^{1}$, Sun Nyunt Wai ${ }^{1}$ and Bernt Eric Uhlin ${ }^{1 *}$

\begin{abstract}
Background: Analysis of the Escherichia coli collection of reference strains (ECOR) for the presence of the gene locus clyA, which encodes the pore-forming protein ClyA (cytolysin A), revealed that a non-functional clyA locus is common among certain extraintestinal pathogenic E. coli (ExPEC). In fact, all 15 ECOR group B2 strains and several additionally examined extraintestinal pathogenic (uropathogenic (UPEC) and neonatal meningitis (NBM)) E. coli strains contained various $\Delta$ clyA alleles.

Results: There are at least four different variants of $\triangle c l y A$, suggesting that such deletions in clyA have arisen at more than one occasion. On the basis of this occurrence of the truncated clyA genes, we considered that there may be a patho-adaptive selection for deletions in clyA in extraintestinal pathogenic E. coli. In E. coli K-12 the clyA gene has been viewed as "cryptic" since it is tightly silenced by the nucleoid structuring protein H-NS. We constructed a restored $\mathrm{ClyA}^{+}$locus in derivatives of the UPEC strain 536 for further investigation of this hypothesis and, in particular, how the gene would be expressed. Our results show that the level of $c l y A^{+}$expression is highly increased in the UPEC derivatives in comparison with the non-pathogenic E. coli K-12. Transcription of the cly $A^{+}$gene was induced to even higher levels when the SfaX regulatory protein was overproduced. The derivative with a restored cly $A^{+}$locus displayed a somewhat slower growth than the parental UPEC strain 536 when a sub-inhibitory concentration of the antimicrobial peptide Polymyxin B was added to the growth medium.
\end{abstract}

Conclusions: Taken together, our findings show that the cly $A^{+}$locus is expressed at an elevated level in the UPEC strain and we conclude that this is at least in part due to the effect of the SfaX/PapX transcriptional regulators.

Keywords: ClyA cytolysin, Pathoadaptive mutations, clyA gene expression, Extraintestinal Escherichia coli, SfaX regulatory protein

\section{Background}

A majority of Escherichia coli strains are benign residents of the intestinal tract of mammals, however a minority of $E$. coli isolates are pathogenic and cause a variety of diseases ranging from diarrhea to urinary tract infections and to meningitis. Genes encoding virulence factors such as adhesins, invasins, and toxins that allow

\footnotetext{
* Correspondence: bernt.eric.uhlin@molbiol.umu.se

'Department of Molecular Biology, the Laboratory for Molecular Infection Medicine Sweden (MIMS), Umeå University, S-90187 Umeå, Sweden Full list of author information is available at the end of the article
}

pathogenic E. coli to colonize, invade, and damage host cells, are often coordinately regulated and tend to be clustered in the genome.

The ability to lyse erythrocytes (hemolysis) by expression of hemolysins is a common feature among E. coli strains causing extraintestinal infections. One of the most characterized hemolysins is HlyA or $\alpha$-hemolysin which is produced by uropathogenic E. coli (UPEC), although several other types of hemolysins have been described for $E$. coli from different patho-groups [1]. The clyA gene, located at $26.5 \mathrm{~min}$ on the $E$. coli chromosome, 
encodes a 34-kDa protein, ClyA (also referred to as HlyE and SheA) which causes lysis of mammalian cells by pore formation in a calcium-independent fashion. ClyA is the only cytolytic factor found in non-pathogenic strains of E. coli including the K-12 strains commonly used in laboratory studies [2-7]. The $c l y A^{+}$transcription is known to be subjected to transcriptional silencing by the $\mathrm{H}-\mathrm{NS}$ nucleoid protein in E. coli $\mathrm{K}-12$ [8] and it can be activated by the transcriptional regulator SlyA $[2,4,5,8]$. Considering the strict regulation of $c l y A$ in non-pathogenic $E$. coli laboratory strains it is of interest to understand how this gene locus functions in other E. coli isolates. Sequences homologous to the $\operatorname{cly} A$ gene have been identified in a number of pathogenic isolates of $E$. coli $[2,6,9,10]$. In addition, upon screening of several different Salmonella enterica serovars, functional homologues to the $c l y A$ gene were identified in the typhoid Salmonella serovars Typhi and Paratyphi A [9]. The presence of the clyA gene in wild-type isolates of Salmonella suggests a conserved function of the gene product although its role in pathogenesis is unclear. Nevertheless, ClyA appears to be associated with virulence in S. enterica. The role of ClyA in Salmonella virulence was analyzed using the S. enterica serovars Brandenburg, Indiana, Panama, and Schwarzengrund; 21 different serotypes of the strains were examined and the presence of ClyA was suggested to be associated with virulence in these S. enterica serovars [11].

In bacteria, the process of adapting to a host may involve not only acquisition of virulence determinants but also loss of gene functions. Pathogenicity-adaptive, or patho-adaptive, mutations may represent a genetic means for enhancing bacterial virulence without horizontal transfer of specific virulence factors, i. e. genes that are detrimental to a pathogenic lifestyle are deleted [12]. Such patho-adaptive mutations, which occur following the acquisition of new genes, may represent fine-tuning of the genome repertoire of a newly created pathogen to adapt to its new pathogenic lifestyle [13]. Earlier studies have provided genetic and/or phenotypic evidence for naturally occurring mutations that are either required for, or dramatically increase the ability of bacteria to enter, spread within, or sustain themselves in a virulence niche $[14,15]$. For instance the spontaneous deletion of $c a d A$, encoding lysine decarboxylase, substantially increases the virulence of entero-invasive E. coli (EIEC) and Shigella spp. [13].

E. coli is considered to be clonal, and phylogenetic analyses of this species have shown that the strains fall into four main groups: A, B1, B2 and D [16]. Recent attempts to establish a link between phylogeny and virulence suggest that the A and B1 phylogenetic groups should be considered to represent the normal flora of different vertebrates, and most human commensal strains originate from these groups [17-19]. The standard Escherichia coli collection of reference strains (ECOR), a set of E. coli strains isolated from diverse hosts and geographic locations, was designed to represent genotypic variation in $E$. coli [20]. The collection contains 72 wild-type E. coli isolates from human and 16 other mammalian species, obtained from a larger collection of approximately 2600 isolates [21]. Our previous results clearly showed that the clyA locus was truncated due to deletion mutations in several of the E. coli isolates [22]. One or more deletions in the clyA locus were found in 15 of 15 tested ECOR B2 strains [22]. Furthermore, deletion mutations in the cly $A$ locus were identified in two of the 25 (8\%) ECOR A strains, one of the $12(8 \%)$ ECOR D strains and one of the four (25\%) ECOR E strains. In contrast, an intact clyA locus was found in $100 \%$ of the 16 ECOR B1 isolates examined. The B2 phylogenetic group represents E. coli strains involved in extra-intestinal infections [19]. The uropathogenic E. coli isolates 536, J96, and five additional (strains AD110, DS-17, IA-2, IH11128 and IHE3034; see Table 1) previously described extra-intestinal pathogenic (uropathogenic E. coli and newborn meningitis $E$. coli (NMEC)) carried a truncated $c l y A$ gene. At least four different variants of $\triangle c l y A$ exist among such strains suggesting that the deletions in cly $A$ arose on more than one occasion [22]. Similar findings have been reported from additional surveys of $E$. coli isolates from different sources [23-25]. Furthermore, the recent study by Murase and coworkers showed that gene inactivation at the clyA locus also has occurred in strains of the ECOR B1 phylogroup [23-25].

In this report we present findings with derivatives of $E$. coli $\mathrm{K}-12$ and the UPEC isolate E. coli 536 in which we constructed a restored $c l y A^{+}$locus as well as a clyA-lux chimeric operon to quantitatively measure expression at the transcriptional level under different growth conditions.

\section{Results}

Deletion mutations at the clyA locus of Escherichia coli

Analysis of the DNA sequences revealed four different variants (denoted I to IV) of the $\triangle c l y A$ alleles and differences in their distribution in the E. coli isolates [22-25]. The strains used in this study are summarized in Table 2 and sequence details are shown in Figure 1. Deletion variant I include two deletions: one major 493-bp deletion spanning from 164 bp upstream to 329 bp downstream of the $\operatorname{cly} A$ translational start codon, and one minor 204-bp deletion spanning from 382 to 585 bp downstream of the clyA translational start codon. Variant I was found in 13 of the 15 ECOR B2 strains, in ECOR23 and ECOR24 of group A, and in the UPEC/NBM isolates AD110, DS17, IA2, IH11128, IHE3034 and J96. Deletion variant II is similar to variant I, but with an intact 1327-bp IS-2 element positioned adjacent to the upstream 493-bp deletion in the opposite orientation of the clyA coding sequence. Variant II was found in ECOR61 and ECOR62 of 
Table 1 Bacterial strains used in this work

\begin{tabular}{|c|c|c|}
\hline Strain & Genotype/relevant characteristics, serotype & Reference/source \\
\hline ECOR collection & E. coli reference collection & {$[20]$} \\
\hline 536 & Clinical UTI isolate, O6:K15:H31 & [26] \\
\hline J96 & Clinical UTI isolate, O4:K6 & [27] \\
\hline JON47 & $J 96 \mathrm{cly} A^{+}\left(\mathrm{Km}^{r}\right)$ & This work \\
\hline JON53 & $536 c^{\prime y} A^{+}\left(\mathrm{Km}^{r}\right)$ & This work \\
\hline COE2 & JON53 clyA-luxAB & This work \\
\hline COE3 & COE3/pAES1 (sfaX $X^{+}$clone) & This work \\
\hline COE4 & COE2/pBR322 & This work \\
\hline COE6 & COE2/pHMG94 (papl ${ }^{+}$clone) & This work \\
\hline AD110 & Clinical UTI isolate, O6:K2:H1:F7 & [28] \\
\hline DS-17 & Clinical UTI isolate, O6:K5 & [29] \\
\hline IA-2 & Clinical UTI isolate, O6: $\mathrm{H}^{-}$ & [30] \\
\hline $1 \mathrm{H} 11128$ & Clinical UTI isolate, $\mathrm{O} 75:{\mathrm{K} 5: \mathrm{H}^{-}}^{-}$ & [31] \\
\hline IHE3034 & Clinical NBM isolate, O18:K1 & {$[32]$} \\
\hline AES1 & sfaX::kan $\left(\mathrm{Km}^{\mathrm{r}}\right)$ mutant of IHE3034 & [33] \\
\hline AES153 & $\triangle$ sfaY mutant of IHE3034 & This laboratory \\
\hline $\mathrm{DH} 5 \mathrm{a}$ & endA1 hsdR17 ( $\left.\mathrm{r}_{\mathrm{k}}^{-} \mathrm{m}_{\mathrm{k}}^{+}\right)$supE44 thi-1 recA1 gyrA relA1 $\Delta$ (lacZYA-argF) & [34] \\
\hline MG1655 & E. coli K-12 wildtype & [35] \\
\hline MC1061 & araD139 $\Delta$ (ara leu)7697 $\Delta$ lacX74galU galK hsr hsm $^{+}$strA & [36] \\
\hline M182 & $\Delta($ lacIPOZY $) \times 74$ galK galU strA & [36] \\
\hline MC4100 & 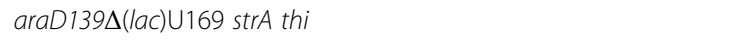 & [37] \\
\hline BSN26 & MC4100 trp::tet $\left(T c^{r}\right)$ & [38] \\
\hline JON33 & BSN26 clyA::/uxAB & [8] \\
\hline MWK11 & MC4100 clyA $A^{++}$ & [8] \\
\hline MWK7 & M182 $\triangle$ clyA & This laboratory \\
\hline
\end{tabular}

group B2. Deletion variant III is similar to variant I with a deletion in the promoter region but in addition had a deletion in the $\operatorname{cly} A$ coding region. Variant III was identified in the UTI isolate 536. Deletion variant IV is a 12-bp-long in-frame deletion from 547 to $558 \mathrm{bp}$ downstream of the clyA translational start. Variant IV was found in the ECOR43 and ECOR44 group E and D, respectively.

The presence of a nearly perfect 10-bp repeat (AGCATTCGCC) immediately upstream of the major 493-bp deletion, and overlapping with the 3 ' end of the deleted segment (AGCATCCGCC) (Figure 1A), suggested that the variant I deletion was the result of a recombination event. We found no such DNA repeats that would explain the internal 204-bp or 217-bp deletions in the $\operatorname{cly} A$ coding sequence (Figure 1B). As shown in the case of variant IV (Figure 1B) a short 5-bp repeat (GCCGG) was identified at the junctions of the 12-bp internal deletion observed in ECOR43 and ECOR44, indicating that this deletion is likely to be the result of a recombination event. The site of insertion of the IS2 element and the generated 5-bp direct repeats (TTCGC) in ECOR61 and ECOR62 suggested that the IS2 element was inserted after the deletion was generated (Figure 2A).

\section{Construction of a restored $c l y A^{+}$locus in the UPEC strain E. coli 536}

To study whether or not the absence of the clyA gene in extra-intestinal $E$. coli isolates reflects that this gene may be disadvantageous for the bacterial cells, cly $A^{+}$derivatives of the UPEC strains 536 and 196 were constructed. We used a suicide plasmid derivative (pJON176) and allelic exchange to introduce the $\operatorname{cly} A$ wild type allele, together with a kanamycin resistance cassette as a selectable marker at $350 \mathrm{bp}$ downstream of the $c l y A$ stop codon, resulting in the strains JON47 (J96 cly $\left.A^{+}\right)$and JON53 (536 cly $\left.A^{+}\right)$, respectively. A schematic illustration of the construct JON53 with restored $\operatorname{cly} A^{+}$locus is shown in Figure $2 \mathrm{~A}$. The strains harboring the $\operatorname{cly} A^{+}$allele at the correct position on the chromosome was confirmed by PCR analysis and DNA sequencing (data not shown). The restored $\operatorname{cly} A$ wild type allele in the UPEC strains was constructed with DNA sequences from E. coli $\mathrm{K}-12$ and it was evident that these 
Table 2 Distribution of truncated and intact clyA loci in the strains of the ECOR collection and additional extraintestinal $E$. coli isolates

\begin{tabular}{|c|c|c|c|c|}
\hline Bacterial strain & Group ${ }^{1)}$ & Serotype & clyA locus present $^{2)}$ & Deletion variant $^{31}$ \\
\hline ECOR1-22, 25 & A & & + & \\
\hline ECOR23-24 & A & & $\Delta$ & । \\
\hline ECOR26-30, 32-34, 45, 58, 67-72 & B1 & & + & \\
\hline ECOR51-57, 59-60, 63-66 & B2 & & $\Delta$ & I \\
\hline ECOR61-62 & B2 & & $\Delta$ & $\|$ \\
\hline ECOR35-36, 38-41, 46-50 & D & & + & \\
\hline ECOR44 & $\mathrm{D}$ & & $\Delta$ & IV \\
\hline ECOR31, 37, 42 & $E$ & & + & \\
\hline ECOR43 & $E$ & & $\Delta$ & IV \\
\hline J96 & UTI & O4:K6 & $\Delta$ & I \\
\hline 536 & UTI & O6:K15:H31 & $\Delta$ & III \\
\hline $\mathrm{H} 11128$ & UTI & $\mathrm{O} 75: \mathrm{K} 5: \mathrm{H}^{-}$ & $\Delta$ & I \\
\hline AD110 & UTI & $\mathrm{O} 6: \mathrm{K} 2: \mathrm{H1}: \mathrm{F} 7$ & $\Delta$ & । \\
\hline DS-17 & UTI & O6:K5 & $\Delta$ & I \\
\hline $\mid A-2$ & UTI & $\mathrm{O} 6: \mathrm{H}^{-}$ & $\Delta$ & । \\
\hline IHE3034 & NBM & $\mathrm{O} 18: \mathrm{K} 1: \mathrm{H7}$ & $\Delta$ & 1 \\
\hline
\end{tabular}

${ }^{11}$ The ECOR subgroups are as defined previously [16].

UTI, urinary tract infection. NBM, newborn meningitis.

${ }^{2)}+$ denotes that an intact $c l y A$ locus is present; $\Delta$ denotes that some deletion(s) had ocurred.

${ }^{3)}$ I-IV denotes the different deletion variants within the clyA locus as described in the text and in Figure 1.

sequences were highly conserved among different $E$. coli. We performed a multiple sequence alignment of the $\operatorname{cly} A$ promoter region and coding sequences using a large set of publicly available $E$. coli genome sequences (NCBI Reference Sequence: NC_000913.3). It included sequences from different $E$. coli pathotypes and from commensally occurring isolates (see Additional file 1). Inspection of the upstream region revealed that sequences corresponding to the transcriptional and translational start sequences with the regulatory sequence elements $(-35,-10$, and Shine-Dalgarno sequences) and binding sites for regulatory proteins (CRP/ FNR, SlyA), as defined from studies of E. coli K-12 derivatives, are conserved among the many different ExPEC and non-ExPEC E. coli isolates with intact $c l y A$ loci.

To assess the level of expression and activity of ClyA in JON47 and JON53, the hemolytic activity of the strains was scored on the blood agar plates. We observed a calcium-dependent hemolytic phenotype in strains JON47 and JON53 when they were grown on blood agar plates. When the $\mathrm{Ca}^{2+}$ chelator $\mathrm{Na}$-oxalate was added (final concentration $2 \mathrm{mM}$ ), all strains showed a non-hemolytic phenotype (Figure 2B, panel i). In our earlier experiments, we showed that lysis of the host bacterial strains promote the release of ClyA using lytic bacteriophages or mitomycin $C$ [9]. To deliberately provoke lysis of the bacterial cells, we placed $2 \mu \mathrm{l}$ of mitomycin $\mathrm{C}$ (from a $1 \mathrm{mg} \mathrm{ml}^{-1}$ stock solution) onto horizontally streaked rows of the strains 536 and J96, and the $\operatorname{cly} A^{+}$derivatives JON47 and JON53 on the blood agar plates (see Methods). Zones of hemolysis appeared for both JON53 (536 cly $A^{+}$) and JON47 (J96 cly $A^{+}$), but not for the parental strains 536 and 596 (Figure 2B, panel ii). The results clearly indicated that the restored $\operatorname{cly} A$ locus in these derivatives (JON53 and JON47) of strains 536 and $J 96$ was expressed and our further tests verified that they could produce the ClyA protein at a detectable level (Figure 2C, lane 2 for strain JON53 and data not shown for strain JON47). The presence of ClyA protein in the $\operatorname{cly} \mathrm{A}^{+}$derivatives was confirmed by Western immunoblotting analysis using polyclonal anti-ClyA antiserum (Figure 2C). Subcellular localization experiments showed that ClyA protein was present in the periplasmic fraction of UPEC derivatives to the same extent as has been found in the case of E. coli K-12 (Figure 2C, lane 7 for strain JON53 and data not shown for strain JON47).

We showed in earlier studies that in $c l y A^{+}$E. coli K-12 derivatives, a small subpopulation of bacterial cells (ca 1-2\%) apparently expressed a high enough level of surface-exposed ClyA to be visible by immunofluorescence microscopy [39]. In order to compare the surface expression and export of ClyA protein in individual bacterial cells of the $c l y A^{+}$UPEC derivative JON53 with the standard E. coli K-12 strain MG1655, we performed immunofluorescence microscopy with anti-ClyA antibodies and with the UPEC strain 536 used as negative control. As shown in Figure 3, ClyA was detected on the surface 


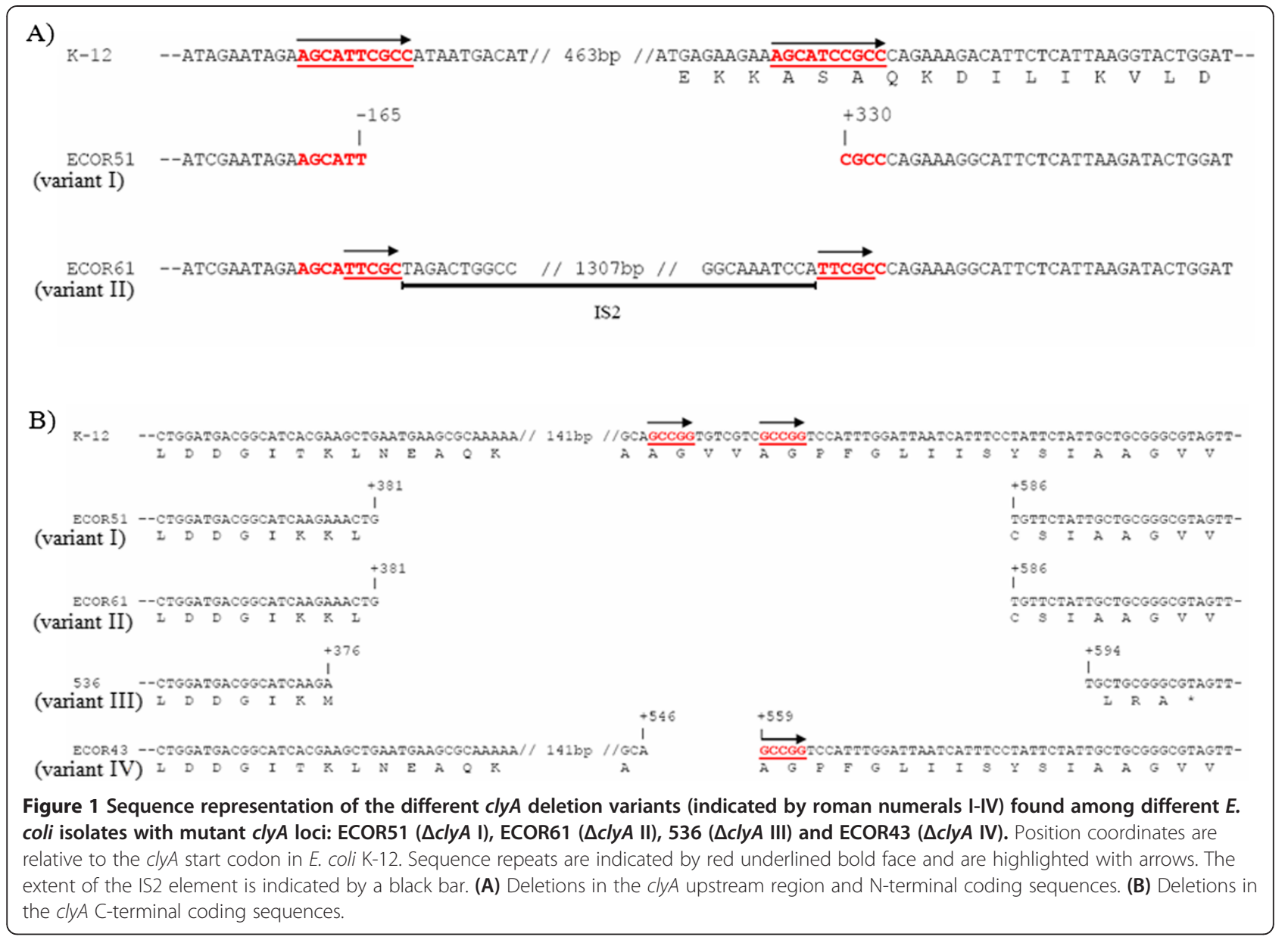

of several JON53 cells whereas there was very little immunofluorescence detected in case of the E. coli $\mathrm{K}-12$ strain MG1655. Taken together, the studies of ClyA expression indicated that protein might be present at a somewhat higher level and/or exposed more abundantly on the surface of the JON53 bacterial cells in comparison with that of the $E$ coli $\mathrm{K}-12$ cells.

\section{Growth phase dependent expression of clyA in JON53}

In order to quantitatively monitor the transcriptional expression level of $\operatorname{cly} A$, a $\operatorname{cly} A:: \operatorname{lux} A B$ operon construct was integrated in tandem to the $\operatorname{cly} A^{+}$locus in the chromosome of JON53 as described in the Methods and schematically depicted in Figure 2A. The resulting strain was designated COE2 (JON53 $\operatorname{clyA}:$ : lux $A B$ ). In our earlier studies, we observed the growth phase dependent expression of the clyA gene in the $E$. coli $\mathrm{K}-12$ derivative carrying the $\operatorname{cly} A:: \operatorname{lu} x A B$ construct (strain JON33) [8]. The transcription level of the $\operatorname{cly} A: \because \operatorname{lu} x A B$ operon in strain COE2 was therefore compared to the level in strain JON33 throughout the growth cycle. As shown in Figure 4A, the luciferase activity of the UPEC derivative COE2 increased continuously during the exponential growth phase and peaked at the late logarithmic phase of growth where it showed a more than five-fold increase compared to the $E$. coli $\mathrm{K}-12 \operatorname{cly} A:: \operatorname{lux} A B$ operon derivative JON33.

\section{Transcription of clyA can be activated by the SfaX/PapX transcriptional regulatory protein family encoded by fimbrial gene clusters in UPEC strains}

In $E$. coli $\mathrm{K}-12$ the transcriptional regulator SlyA is known to activate $\operatorname{cly} A^{+}$transcription by counteracting the silencing the H-NS nucleoid protein is causing $[2,4,5,8]$. However, the $\operatorname{sly} A$ gene seems to be present in most, if not all, $E$. coli and the same is true for the hns gene, suggesting that their role in $\operatorname{cly} A$ transcriptional regulation (anti-silencing vs. silencing) would be conserved among different nonpathogenic and pathogenic $E$. coli. Nevertheless, we performed a multiple sequence alignment of the slyA promoter region and coding sequences using a large set of publicly available $E$. coli genome sequences (NCBI Reference Sequence: NC_000913.3) to see if there would be any differences hinting to altered regulation of $s l y A$ expression among different $E$. coli. It included sequences from different E. coli pathotypes (ExPEC and non-ExPEC) and from 


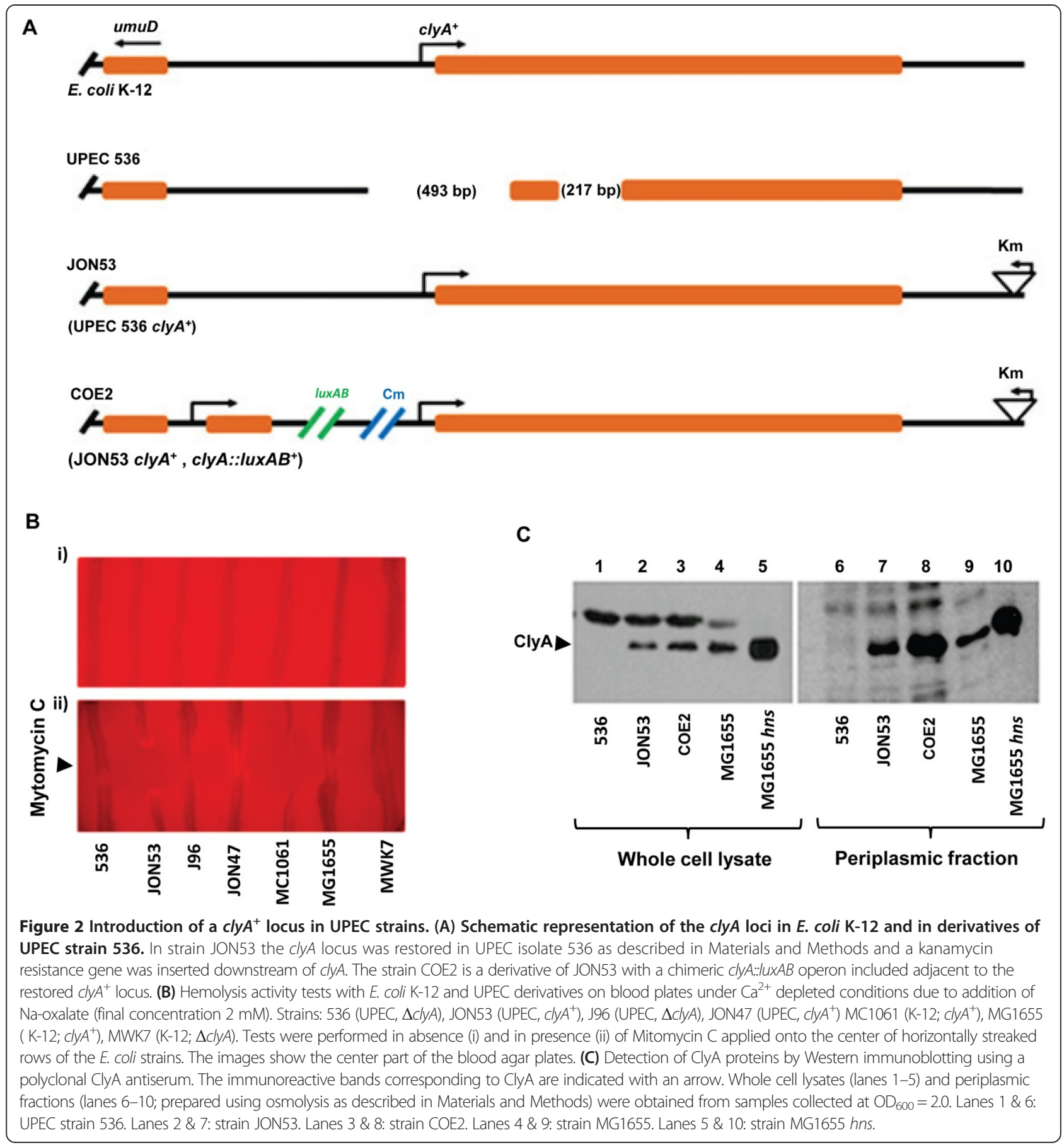

commensally occurring isolates. Inspection of the upstream region revealed that sequences corresponding to the transcriptional and translational start sequences with the regulatory sequence elements $(-35,-10$, and ShineDalgarno sequences), as defined from studies of $E$. coli K-12 derivatives, are completely conserved among the many different $E$. coli isolates indicating that there would be no obvious difference in sly $A$ expression and regulation (data not shown).
Recent studies have shown that there are regulatory proteins (the SfaX/PapX protein family) that show resemblance to the SlyA protein and are encoded by genes in fimbrial gene clusters typically occurring in UPEC isolates but which are absent in E. coli K-12 [40-42]. We therefore decided to investigate if the SlyA-like regulator SfaX might influence the expression of the $c l y A$ locus. In UPEC strain 536 there are two fimbrial gene clusters, $s f a$ and prs that include genes for such regulatory proteins, SfaX and PrsX, 


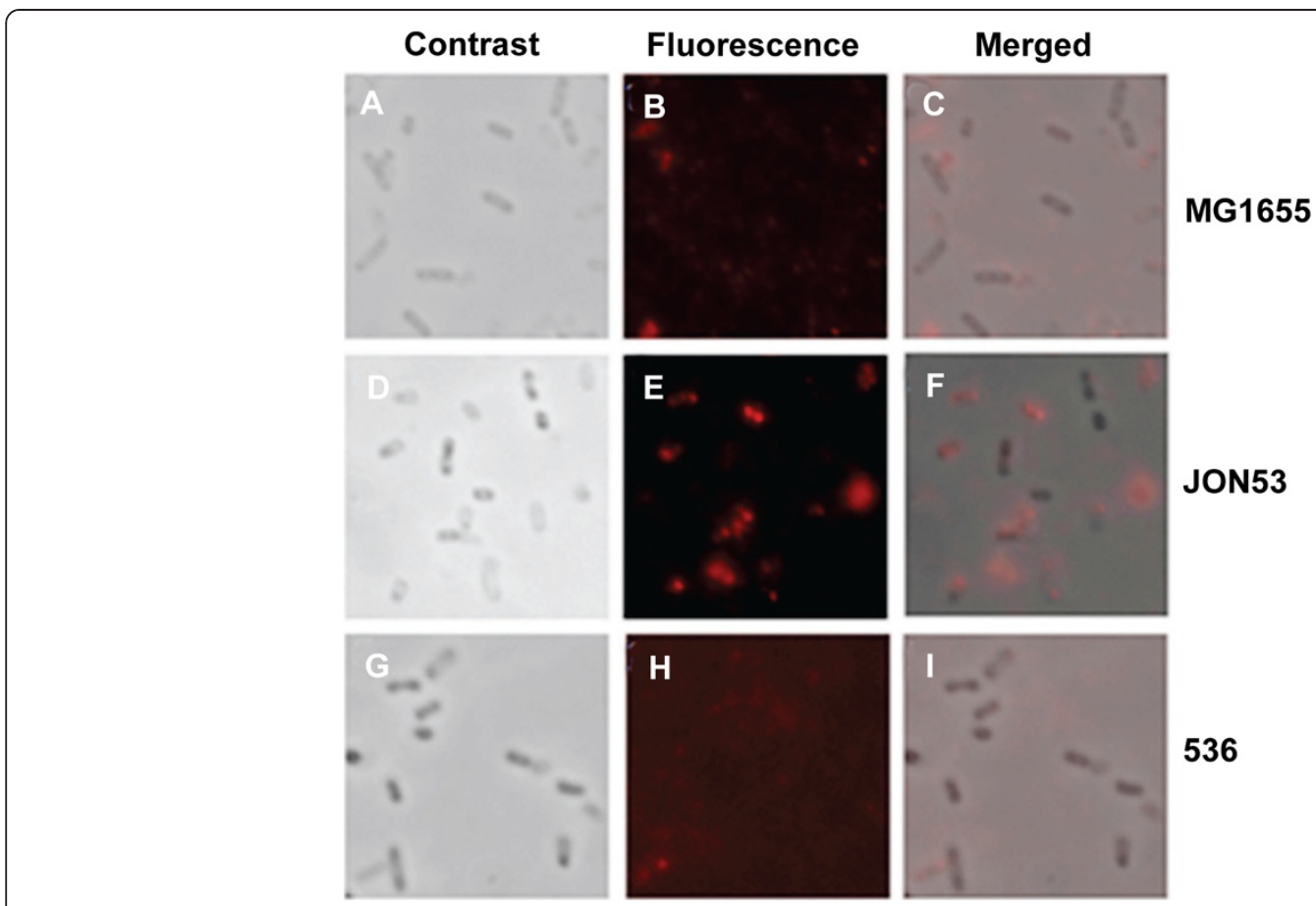

Figure 3 Immunofluorescence microscopy detection of ClyA on bacterial cells. Analyses were done with the E. coli K-12 strain MG1655 (A, B C), the clyA $A^{+}$UPEC derivative JON53 (D, E, F) and the parental UPEC strain $536(\mathbf{G}, \mathbf{H}, \mathbf{I})$. Panels A, D, G show images obtained by by phase contrast microscopy. Panels $\mathbf{B}, \mathbf{E}, \mathbf{H}$ show images obtained from immunofluorescence analysis using polyclonal ClyA antiserum and AlexaFluor ${ }^{555}$ -conjugated secondary antibody to enable visualization of ClyA as a red fluorescence signal. Panels $\mathbf{C}, \mathbf{F}$, I show the merged images.

respectively. In order to specifically test if the SfaX protein can influence expression of $c l y A$ we performed tests with the $s f a X^{+}$wildtype and a mutant derivative of the ExPEC strain IHE3034 which is known to have only one copy of the $s f a X$ gene family [41]. A plasmid construct with the $c l y A^{+}$gene under control of its natural promoter region was introduced into strain IHE3034 and the sfaX::kan derivative AES1. A mutant derivative (AES153) defective in the $s f a Y$ gene located immediately upstream of $s f a X$ in the same operon was also included. The SfaY protein is predicted to function as a c-di-GMP phosphodiesterase and thereby indirectly involved also in the activity of the transcriptional regulator SfaX [41]. It is also postulated that the $s f a Y$ mutation is causing a polar effect that may reduce sfaX expression. The phenotypic test of ClyAmediated hemolytic activity showed that colonies of the wildtype strain IHE3034 caused stronger hemolysis than the mutant derivatives indicating that its expression and/ or release of ClyA was higher than that of AES1 and AES153 (Table 3). Western immunoblot analysis of ClyA protein levels, using the plasmid encoded enzyme $\beta$ lactamase as reference, indicated that the $s f a X^{+} s f a Y^{+}$wild type bacteria produced a somewhat higher level of ClyA than the mutant derivatives (Figure 5).

As a more direct assessment of the potential influence of the sfaX/papX regulatory gene products on clyA gene transcription in a UPEC strain we tested what effect overproduction of SfaX protein might have. A plasmid with the cloned $s \mathrm{faX}^{+}$gene was introduced into the UPEC derivative COE2 carrying the $\operatorname{cly} A: \operatorname{lu} x A B$ operons construct in the chromosome. For comparison we included a test with another regulator, the PapI protein known to be part of a regulatory protein complex at the major promoter region of the pap and sfa fimbrial gene clusters in UPEC isolates [41]. The strain carrying the plasmid with the $s f a X^{+}$ gene (pAES1) was named COE3, a vector plasmid control strain was named COE4, and the strain carrying the plasmid with the papI $I^{+}$gene (pHMG95) was named COE6. Samples for Luciferase activity measurements were taken during the growth of these strains in LB medium (Figure 6A). The results demonstrated that the UPEC strain carrying the $s f a X^{+}$plasmid (strain COE3) had a greatly enhanced level of $c l y A$ transcription. No such effect was seen with the papI ${ }^{+}$clone (strain COE6). These results strongly support the suggestion that the presence of $\mathrm{SfaX}$ protein in UPEC isolates can cause up-regulation of $c l y A$ gene expression and that the effect could be stronger with higher levels of SfaX/PapX proteins in such E. coli strains.

The clyA $A^{+}$derivative of UPEC strain E. coli 536 has increased susceptibility to the antimicrobial peptide Polymyxin B

Considering the relatively high expression levels of the pore-forming protein in the UPEC derivatives, we 


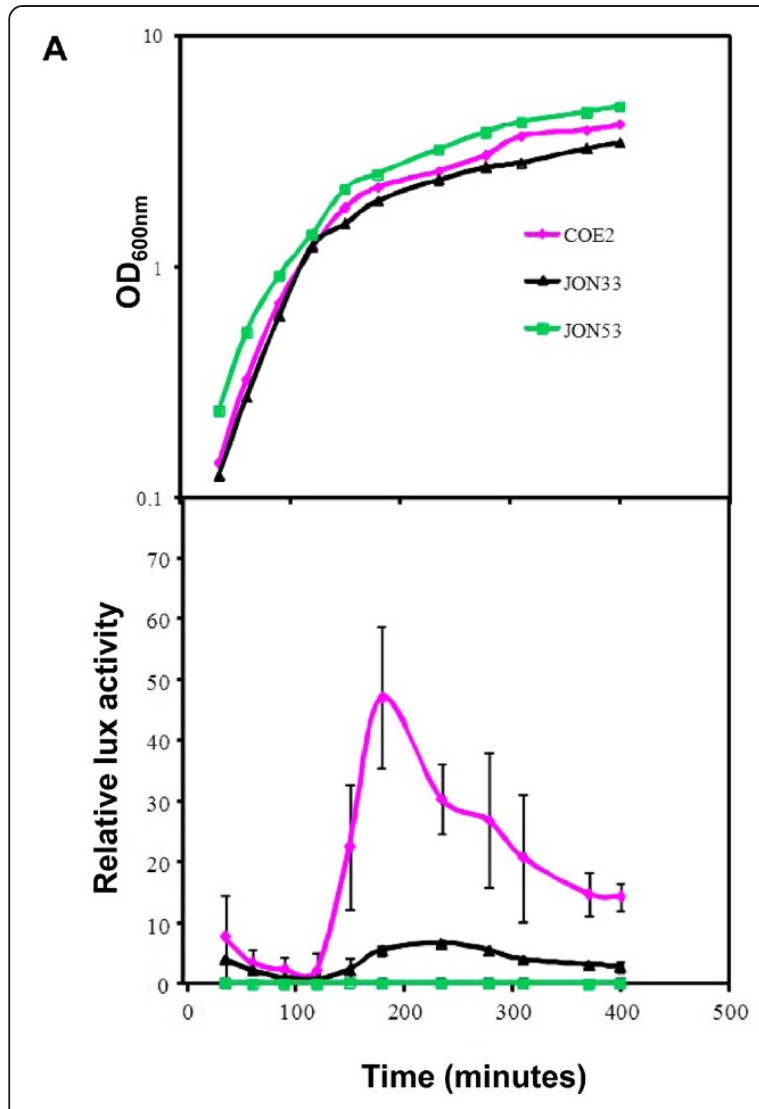

B

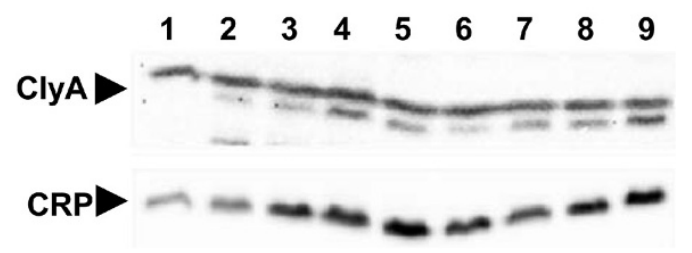

Figure 4 Growth phase dependent clyA transcription. Bacteria were grown in $L B$ medium (A) at $37^{\circ} \mathrm{C}$ and samples were assayed for luciferase activity as described in Materials and Methods. The strains tested were: the UPEC derivative COE2 (clyA.:luxAB), the E. coli K-12 strain BSN26 (clyA:IJXAB) and the UPEC strain 536 clyA (JON53) which was serving as a luciferase negative control. The growth curves (upper panel) are presented from a representative experiment. The data curves for luciferase activity (lower panel) represent the average value of three independent experiments and vertical bars indicate the standard deviations. (B) Immunoblot detection of ClyA and CRP proteins. The immunoreactive bands corresponding to ClyA and CRP are indicated with arrows. Bacteria were grown in $\mathrm{LB}$ medium at $37^{\circ} \mathrm{C}$. Whole cell lysates were prepared from samples collected during different growth phases from the logarithmic phase of growth until the stationary phase. Lane 1: UPEC strain 536. Lanes 2-5: strain JON53, $\mathrm{OD}_{600}=1.6$ (lane2), $\mathrm{OD}_{600}=1.74$ (lane 3), $\mathrm{OD}_{600}=2.24$ (lane 4) and $\mathrm{OD}_{600}=2.7$ (lane 5). Lanes 6-9: $\mathrm{COE} 2, \mathrm{OD}_{600}=1.5$ (lane 6), $\mathrm{OD}_{600}=1.8$ (lane 7), $\mathrm{OD}_{600}=2.04$ (lane 8) and $\mathrm{OD}_{600}=2.5$ (lane 9).

decided to test the possibility that restoration of the cly $A$ locus in strain 536 might influence its cell wall or membrane properties and perhaps change its susceptibility to antimicrobial compounds directed towards membranes.
The strain JON53 was therefore cultured in medium supplemented with serially diluted concentrations of different antimicrobial peptides (Polymyxin B, $\beta$-defensin and LL-37), and with different concentrations of urea or creatinine. We compared the MIC values for each antimicrobial compound with the parental strain 536 and the $\operatorname{cly} \mathrm{A}^{+}$derivative JON53. Our preliminary studies indicated that there was no difference in MIC values between the two strains for either of the tested compounds (Polymyxin B, $\beta$-defensin or LL-37; data not shown). Likewise, there were no differences detected when different concentrations of creatinine in the medium were tested. However, when a sub-inhibitory concentration $(0,39 \mu \mathrm{g} / \mathrm{ml}$, i.e. half the concentration of the observed MIC value $0,78 \mu \mathrm{g} / \mathrm{ml}$ ) was present in the medium the $\operatorname{cly} A^{+}$derivative JON53 displayed a somewhat slower growth in presence of Polymyxin $\mathrm{B}$, manifested as a more prolonged lag, than the parental UPEC strain 536 (Figure 7A). The normal AUM medium contained $170 \mathrm{mM}$ urea. At a two-fold higher concentration $(340 \mathrm{mM})$ of urea also the parental UPEC strain 536 seemed more susceptible to the effect of the sub-inhibitory concentration of Polymyxin B (Figure 7B). At even higher concentrations of urea (510 $\mathrm{mM}$ or $680 \mathrm{mM}$ ) the presence of Polymyxin B per se did not seem to alter the growth much but both strains showed reduced growth. Notably, it was evident that the higher concentrations of urea affected growth of the $c l y A^{+}$derivative JON53 more than that of the parental $\triangle c l y A$ UPEC isolate (Figure 7C \& D).

The effect of Polymyxin B on growth was also monitored with the E. coli K-12 strains MC4100 and MWK11, the latter being a derivative of MC4100 with a constitutive expression of ClyA protein due to an improved binding site near the promoter for the cAMPCRP activating complex [8]. These strains showed a similar MIC value $(0,78 \mu \mathrm{g} / \mathrm{ml})$ for Polymyxin B as the UPEC strains. In the growth test with Polymyxin B at half the MIC value $(0,39 \mu \mathrm{g} / \mathrm{ml})$ the higher ClyA expression did not cause any apparent disadvantage but when Polymyxin B was added at a somewhat higher concentration $(0,48 \mu \mathrm{g} / \mathrm{ml})$ the $\mathrm{ClyA}^{+}$phenotype was correlated to reduced growth also in the case of the E. coli $\mathrm{K}-12$ derivatives (see Additional file 2).

\section{Discussion and conclusions}

In Escherichia coli several different pore-forming cytolysins have been identified. The one most extensively studied is $\alpha$-hemolysin (HlyA), which is produced by many uropathogenic E. coli (UPEC) strains and contributes to virulence as shown in several animal models [43]. The biological role of the ClyA protein, representing a novel family of non-RTX toxins in Enterobacteriaceae, remains to be discovered, although the distribution of the clyA locus in a wide array of isolates would indicate that it has an evolutionarily conserved function. The $c l y A$ gene 
Table 3 Phenotypic test performed on blood agar plate ${ }^{1)}$ Bacterial strain Hemolytic phenotypes

IHE3034 (sfaX $)^{+}$

AES1 (sfaX::kan)

AES153 ( $\triangle$ sfaY)

IHE3034/pYMZ81

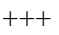

AES1/PYMZ81

$++$

AES153/pYMZ81

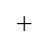

IHE3034/pUC18

AES1/pUC18

AES153/pUC18

${ }^{1)}$ The strains were grown on double blood agar plate and incubated overnight at $37^{\circ} \mathrm{C}$ prior to analysis of the phenotypes. (+++ = Strong hemolysis, $++=$ Weak hemolysis, $+=$ very weak hemolysis and $-=$ No hemolysis).

is clearly conserved in Enterobacteria, i. e., in many $E$. coli isolates and in typhoid serovars of Salmonella enterica $[2,6,9,10]$.

A functional $c l y A$ gene was evidently lost through deletion(s) in several E. coli strains, e. g., in 19 of the 72 ECOR strains, and the $\triangle c l y A$ alleles were present in a number of different variants. Some strains carried various deletions in the $\operatorname{cly} A$ coding sequence and in the upstream region, resulting in truncated $c l y A$ loci. In the majority of cases $(\triangle c l y A$ versions I, II and III), the function of the $\operatorname{cly} A$ locus may be effectively abolished by two deletions, removing the promoter region and portions of the $\mathrm{N}$-terminal and central regions of the coding sequence. In ECOR43 and ECOR44, a 12-bp in-frame deletion (corresponding to amino acids 183-
186 in ClyA) results in the expression, at a level similar to that of the $\operatorname{cly} A^{+}$derivative JON53, of a ClyA polypeptide that was found to have no or very low hemolytic activity (our unpublished data). The presence of short repetitive DNA sequences at the junctions of the major 493-bp deletion in $\triangle c l y A$ variants I-III (Figure 1A) and the 12-bp deletion of $\triangle c l y A$ variant IV (Figure 1B) suggests that these deletions may have been formed as a result of slippage mispairing. The role of direct repeats in deletion formation has been demonstrated by sequence analysis of several deletion mutants in $E$. coli [44-46]. Since no such repeats were identified at the junctions of the other deletions, i. e. the 203- or 217-bp deletions in $\triangle c l y A$ variants I-III (Figure 1B), these deletions appear to have arisen by some other mechanism(s). They could be the result of subunit exchange between DNA gyrase molecules, since this model has been suggested for deletions terminating in sequences that are neither directly nor inversely repeated $[47,48]$. It also appears that after the functionality of a $\operatorname{cly} A$ locus was lost, further alterations occurred, e.g., insertion of an IS-2 element (strains ECOR61 and ECOR62), and nonconservative point mutations in the clyA coding sequence.

Considering the possibility that there might be some patho-adaptive selection for mutations in $\operatorname{cly} A$ of some $E$. coli we restored, and studied the expression of, a functional gene locus in the chromosome of the UPEC isolate 536.

In order to determine if regulatory genes of fimbrial gene clusters typically present in the chromosome of UPEC can upregulate the expression of $\operatorname{cly} A$, a plasmid
A

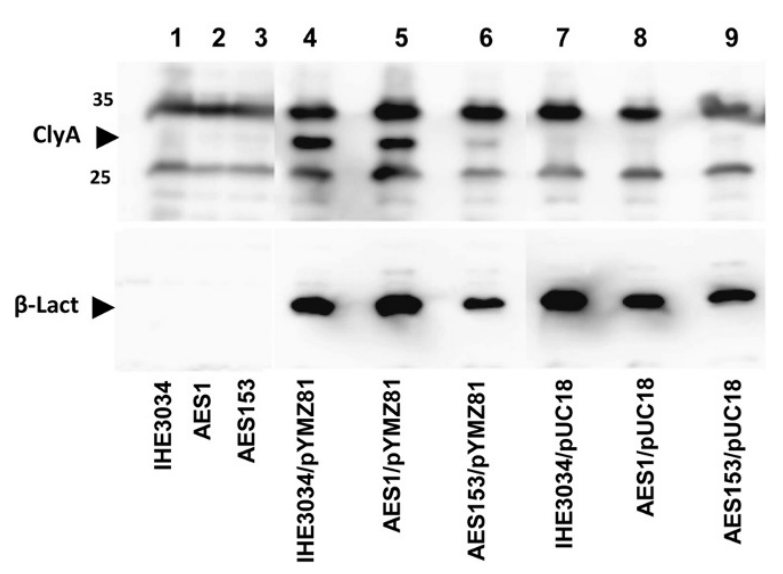

B

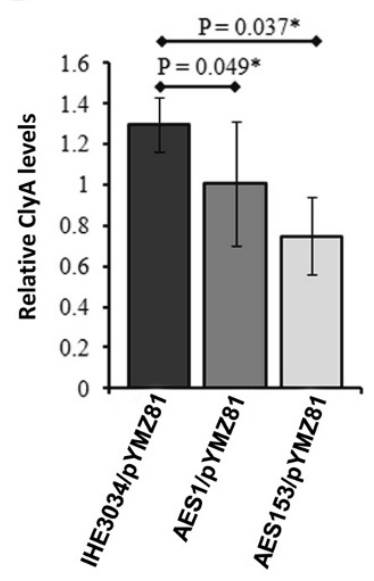

Figure 5 ClyA protein levels in derivatives of ExPEC strain IHE3034. (A) Effect of the sfaX-Y genes on the relative levels of ClyA protein. Samples were taken from cultures grown in LB medium at $37^{\circ} \mathrm{C}$ of the following strains: lane 1, IHE3034 (sfaX ${ }^{+}$); lane 2, AES1 (sfaX::kan); lane 3, AES153 ( $\triangle$ sfaY); lane 4, IHE3034/pYMZ81; lane 5, AES1/pYMZ81; lane 6, AES153/pYMZ81; lane 7, IHE3034/pUC18; lane 8, AES1/pUC18; lane 9, AES153/pUC18. The immunoreactive bands corresponding to ClyA and the plasmid encoded $\beta$ - Lactamase (used as the control in this experiment) are indicated with arrowheads. (B) Quantification of relative ClyA levels in the strains IHE3034/pYMZ81 and AES1/pYMZ81 calculated from the ratios of ClyA and $\beta$-Lactamase levels as monitored in the image analyzer (see Methods). The data represent the average value of three independent experiments and vertical bars indicate the standard deviations. An asterik indicates significance in difference according to Student's $t$-test. 


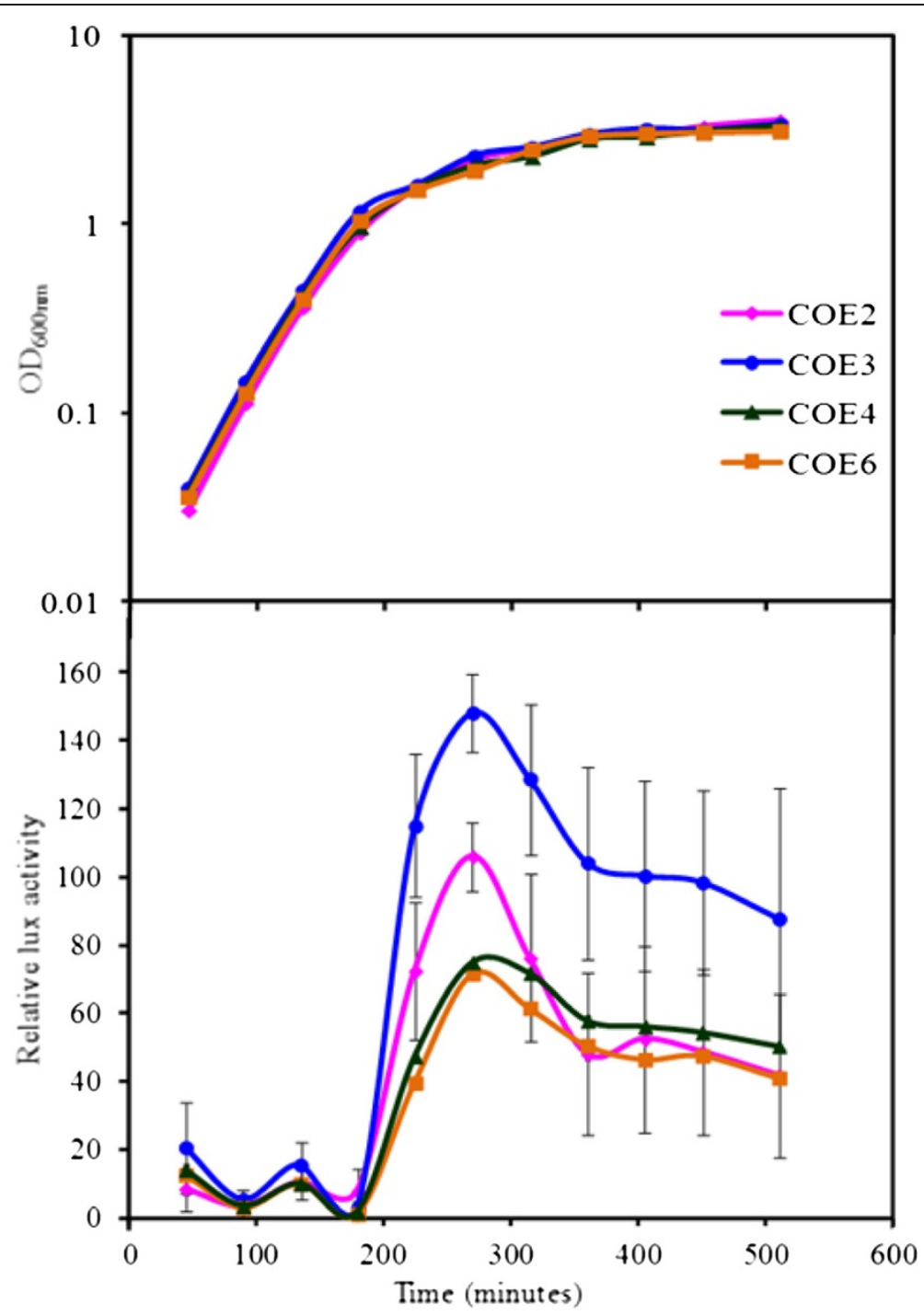

Figure 6 Effect of SfaX protein overproduction on expression of clyA. Transcription of clyA was monitored by luciferase measurements with the clyA::luXAB UPEC restored construct COE2 carrying different plasmids as follows: COE2 carrying the sfa $X^{+}$plasmid clone PAES1 (COE3), COE2 carrying the vector pBR322 (COE4) and COE2 carrying the pap ${ }^{+}$plasmid clone pHMG95 (COE6). The bacteria were grown in LB medium

(Figure 6) and the growth curve data are from representative experiments. The data showing relative Lux activities represent the average values of three independent experiments and vertical bars indicate the standard deviations.

carrying the $s f a X$ gene was introduced into the restored UPEC derivative and we observed that the level of ClyA was upregulated at the early stationary phase of growth. Therefore, the $s f a X$ gene does upregulate $c l y A$ expression.

Although the prevalence of $E$. coli strains with an intact $\operatorname{cly} A$ gene in the ECOR A and B1 groups would support the argument that ClyA has no direct role in virulence, it cannot be ruled out that pathogenic rather than non-pathogenic isolates under certain conditions may express higher levels of ClyA and/or more efficiently translocate the protein. In contrast to the commensal strains, extraintestinal pathogenic $E$. coli are mostly derived from group B2 and, to a lesser extent, from group D [17-19]. There is a phylogenetically clustered distribution of the virulence-associated determinants alpha-hemolysin ( $h l y)$, type-II capsule (kps), and $\mathrm{P}($ pap) and S (sfa) fimbriae in the E. coli B2 and D groups [18], and it has been suggested that the B2 strains should be considered highly virulent as evidenced by a mouse model of extra-intestinal virulence [19]. Hence, the fact that every one of the 15 strains in the B2 group of the ECOR collection contained a $\triangle c l y A$ allele [22] strongly suggests that $E$. coli strains adapted for an extraintestinal lifestyle have the $c l y A$ gene deleted. On the other hand, it does not necessarily imply that some selective condition(s) or mechanism(s) must be found in the extraintestinal locations where E. coli may reside. 


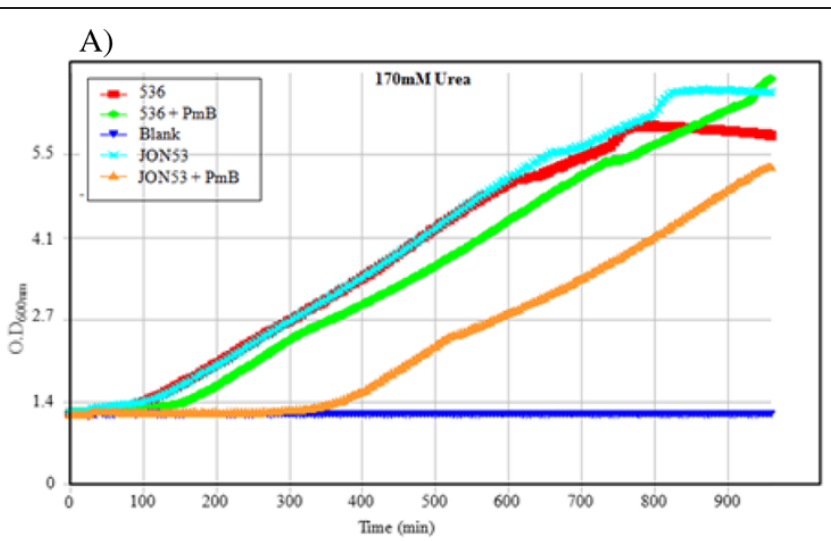

B)

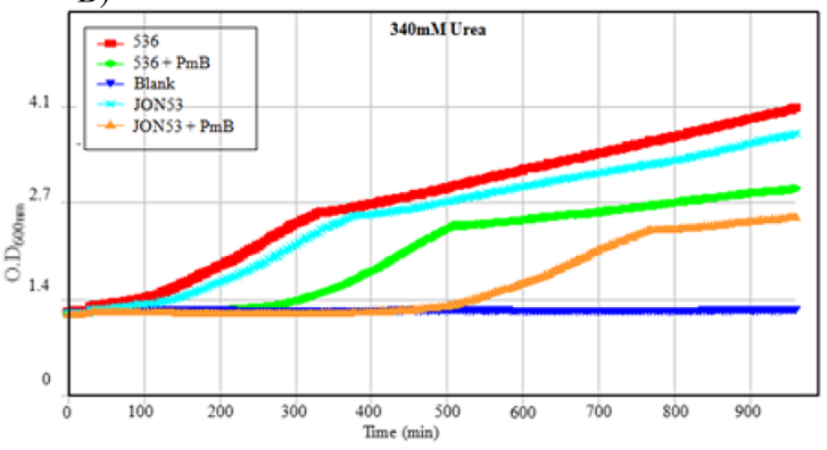

C)

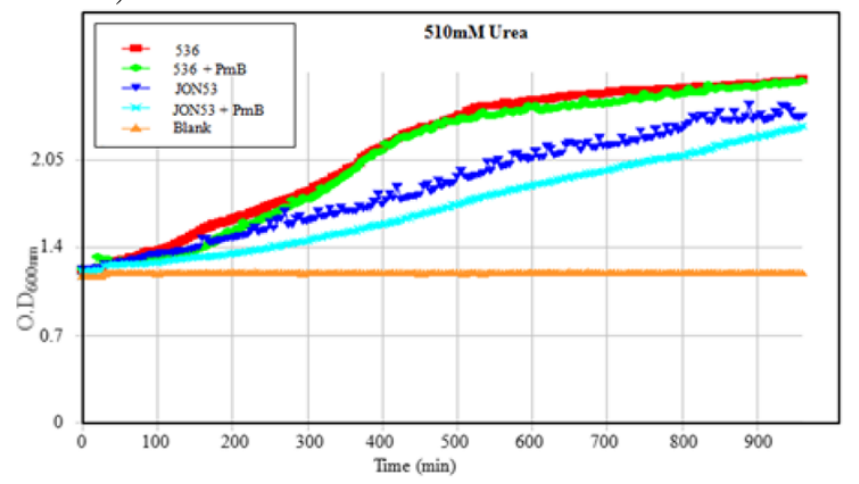

D)

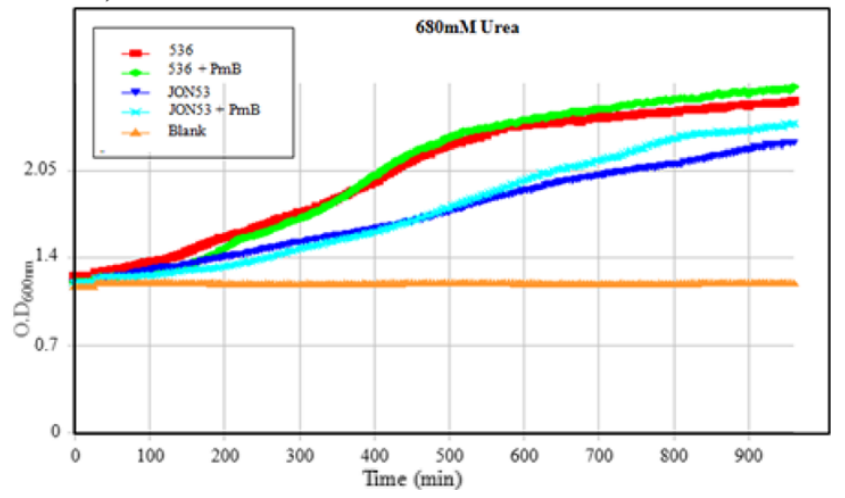

Figure 7 (See legend on next page.) 
(See figure on previous page.)

Figure 7 Effect of Polymyxin B at a sub-inhibitory concentration on the growth of UPEC strain 536 and the cly $A^{+}$derivative JON53.

Note that the color codes for the strain JON53 and the blank are changed between panels A-B to C-D. The growth was monitored as optical density at $\mathrm{OD}_{600 \mathrm{~nm}}$ and the plots show growth in presence of $0.39 \mathrm{\mu g} / \mathrm{ml}$ of Polymyxin B which is a concentration at half the observed MIC value $(0.78 \mathrm{\mu g} / \mathrm{ml})$ in AUM medium with the following concentrations of urea: A) $170 \mathrm{mM}$; B) $340 \mathrm{mM}$; D) $510 \mathrm{mM}$; D) $680 \mathrm{mM}$.

In a study using multilocus enzyme electrophoresis and sequencing of the $m d h$ housekeeping gene, it was concluded that pathogenic strains of $E$. coli do not have a single evolutionary origin but have arisen on several occasions [49]. Similarly, it appears unlikely that there is a common ancestor for all $\triangle c l y A$ strains, e. g. two ECOR strains in the A group and one in the $\mathrm{E}$ group were $\triangle c l y A$. The presence of different variants of the truncated $\operatorname{cly} A$ locus suggests that $\operatorname{cly} A$ is a preferred target for deletion mutations, and that such deletions have arisen on several independent occasions. The adaptation to a particular host may involve loss of virulence traits that are important for infection of a wider spectrum of animals [50]. Similarly, it is possible that the cly $A$ locus could be inactivated in the process of acquisition of new genes (e. g., genes in PAIs) that would promote transition to an extra-intestinal lifestyle. One hypothesis consistent with our present findings would be that the strict regulation of clyA could be lost during this transition. In E. coli $\mathrm{K}-12$ the $\operatorname{cly} A$ locus is strictly regulated and its expression is silenced by the H-NS protein [39]. One plausible explanation for the strict regulation in case of such genes appearing as cryptic/silenced would be that less strictly controlled alleles of such genes are disadvantageous to the bacteria under certain environmental conditions [51]. In this context it may be interesting to carry out further studies with strains from ECOR group D that seem to have an intact $c l y A^{+}$locus whereas it remains to be established if they produce ClyA protein and how expression is controlled.

In previous studies, it was demonstrated that epithelial cells of the urinary tract in humans and mice secrete an antimicrobial peptide, cathelicidin, upon contact with UPEC and that the severity of the bacterial invasion is linked to bacterial resistance to cathelicidin [52]. While we did not detect any effect of the tested cathelicidin (LL-37) on the growth of the bacteria, it remains to be determined if the $c l y A^{+}$UPEC derivative is more susceptible to such peptides under in vivo conditions. We may hypothesize that the mutations in the $\operatorname{cly} A$ gene were selected for either under growth-limiting antimicrobial peptide stress conditions in the urinary tract to which bacterial cells are maladapted or under some other condition of stress for example in the intestine where likewise the combination of a $\operatorname{cly} A^{+}$allele and some other trait(s) might be unfavourable. The mutations in the clyA gene may adapt the bacteria to this stress condition and thereby contribute to the bacterial survival as pathoadaptive events. The constructs described in this work should allow us to test such hypotheses in suitable model infection systems.

In order to test the potential impairment of membrane integrity in the restored strain, the JON53 strain was cultured in presence of the antimicrobial peptide Polymyxin $\mathrm{B}$ which can disrupt the integrity of the bacterial cell membrane by interacting with its phospholipids. The MIC value for Polymyxin B of JON53 was not altered in comparison with the wild type UPEC strain 536 although there was a clearly detectable negative effect on the growth of the $\operatorname{cly} A^{+}$derivative JON53 when Polymyxin $\mathrm{B}$ was added at a sub-inhibitory concentration. Also higher concentrations of urea in the medium caused this differential effect on the growth of the two strains.

Although a rather preliminary finding that will need to be studied further, the observed higher susceptibility to the antimicrobial peptide Polymyxin B that was seen in the case of the UPEC with a restored $c l y A^{+}$locus would suggest that such a phenotype is more of a disadvantage in the intestinal locations where other bacteria, e.g. Bacillus, are producing antimicrobial peptides.

\section{Methods}

\section{Bacterial strains and growth conditions}

Sources and relevant characteristics of the bacterial strains and plasmids used in this study are listed in Table 1 and Table 4, respectively. Bacterial strains were grown aerobically at $37^{\circ} \mathrm{C}$ on $\mathrm{LB}$ broth solidified with $1.5 \%(w / v)$ agar, or in Luria-Bertani (LB) broth, Poor Broth (PB) [53], or artificial urine medium (AUM) [54]. Blood agar plates consisted of $5 \%$ horse erythrocytes solidified with $1 \%(\mathrm{w} / \mathrm{v})$ Columbia-Agar (base) (Merck), which according to the manufacturer contains $2.3 \%$ $(\mathrm{w} / \mathrm{v})$ special nutrient substrate. $\mathrm{Ca}^{2+}$ depleted conditions were obtained by supplementing the blood agar plates with Na-oxalate (final concentration $2 \mathrm{mM}$ ). Antibiotic selection was performed using $30 \mu \mathrm{g} / \mathrm{ml}$ kanamycin, $12.5 \mu \mathrm{g} / \mathrm{ml}$ chloramphenicol, $50 \mu \mathrm{g} / \mathrm{ml}$ carbenicillin or $15 \mu \mathrm{g} / \mathrm{ml}$ tetracycline.

\section{Genetic techniques}

Oligonucleotides were obtained from DNA Technology, Aarhus, Denmark or from TAG Copenhagen, Copenhagen, Denmark. DNA sequencing was performed using the ABI PRISM $^{\mathrm{TM}}$ Dye Terminator Cycle Sequencing Ready Reaction Kit with AmpliTaq ${ }^{\bullet}$ DNA Polymerase, and an ABI PRISM ${ }^{\text {тм }}$ 377 DNA Sequencer. For PCR-screening, cloning and 
Table 4 Plasmids used in this work

\begin{tabular}{|c|c|c|}
\hline Plasmid & Relevant characteristics & Reference/source \\
\hline pBR322 & Cloning vector, $T c^{r}$ & {$[55]$} \\
\hline pGEM ${ }^{\oplus}-\mathrm{T}$ Easy & T-vector for cloning of PCR-fragments, $\mathrm{Cb}^{r}$ & Promega \\
\hline pJON77 & 3.1-kb subclone of clyA in pSL1180, Cbr & This work \\
\hline pJON78 & 3.1-kb subclone of clyA in pKO3, $\mathrm{Cm}^{\mathrm{r}}$ & This work \\
\hline pJON176 & $\mathrm{clyA}^{+}$kan in pJON78, $\mathrm{Cm}^{r} \mathrm{Km}^{r}$ & This work \\
\hline pKO3 & Gene replacement vector, $\mathrm{Cm}^{\mathrm{r}}$ & {$[56]$} \\
\hline pMWK4 & clyA::/uxAB in pCH257, $\mathrm{Cm}^{r}$ & [8] \\
\hline pAES1 & pBR322, $s f a X_{\|}$gene from $s f a_{\|}$operon & [41] \\
\hline pHMG95 & pBR322, lacP(UV5)papl $I^{+}$clone & [57] \\
\hline pSL1180 & Cloning vector, $\mathrm{Cb}^{\mathrm{r}}$ & [58] \\
\hline pUC4K & Kanamycin resistance gene cartridge plasmid, $\mathrm{Kan}^{\mathrm{r}}$ & [59] \\
\hline pUC18 & Cloning vector, $\mathrm{Cb}^{r}$ & {$[60]$} \\
\hline pYMZ81 & A $1.6-\mathrm{kb}$ clyA locus in pUC18 & {$[8]$} \\
\hline pYMZ62 & 3.5-kb subclone of clyA in pUC18 & [8] \\
\hline
\end{tabular}

sequencing of $c l y A$-like genes we used the oligonucleotide primers umu1 (5'-AATATTTGTCGCTGC-3') and p79 (5'-TGTCAACAGGTAACTCTC-3'). The primers umu1 and p79 amplify a 1292-bp fragment starting 293 bp upstream of the clyA start codon and ending 87 bp downstream of the stop codon, based on the sequence of the E. coli $\mathrm{K}-12$ clyA locus $[2,61]$ and our data. Cloning of PCRamplified $c l y A$-like sequences was performed using the pGEM ${ }^{-}$T Easy Vector System of Promega, as specified by the manufacturer, and DH5 $\alpha$ as a host strain.

\section{Plasmid and strain construction}

To construct cly $A^{+}$derivatives of E. coli 536 and J96, we used the suicide plasmid pJON176 containing the cly $A$ wild type allele and a kanamycin resistance cassette located $350 \mathrm{bp}$ downstream of the $\operatorname{cly} A$ stop codon. The construction of pJON176 was done as follows: A 3.5-kb $P v u I I$ restriction fragment from plasmid pYMZ62 containing the $\operatorname{cly} A$ locus region (between nucleotide positions $1,227,641$ and $1,231,223$ in the E. coli $\mathrm{K}-12$ genome) was inserted into EcoRV-digested pSL1180 which resulted in the construction of pJON77. The plasmid pJON77 was digested to yield a 3.2-kb PvuII$B a m H I$ fragment that was subsequently ligated into the BamHI-SmaI-digested pKO3 suicide donor plasmid thus resulting to the construct $\mathrm{pJON78.} \mathrm{A} \mathrm{1.3-kb} \mathrm{PstI} \mathrm{restric-}$ tion fragment which contains the kanamycin resistance gene from the plasmid pUC4K was then ligated into the Nsi I restriction site of pJON78, i. e. 350 bp downstream of the $\operatorname{cly} A$ stop codon, to generate the construct pJON176. The clone included the entire $0,4 \mathrm{~kb}$ intercistronic region and sequences into the $u m u D$ gene upstream of $\operatorname{cly} A$ such that the otherwise deleted promoter region in the UPEC strains could be restored.
Using pJON176 the clyA locus and kanamycin resistance gene was introduced into the chromosome of the $E$. coli strains 536 and J96, as previously described [54], to generate the strains JON53 and JON47, respectively.

For the purpose of quantitatively determining the level of $\operatorname{cly} A$ gene transcription, we introduced a $\operatorname{cly} A-\operatorname{lux} A B$ operon construct using the suicide plasmid pMWK4 [8]. The pMWK4 plasmid contains DNA corresponding to the sequence 290 bp upstream of $c l y A$ and 76 bp into the $\operatorname{cly} A$ coding sequence. The pMWK4 plasmid was integrated in tandem to $\operatorname{cly} A$ in the chromosome of JON53 by a single recombination event. The resulting strain was designated COE2 (JON53 - clyA::luxAB).

The plasmids pAES1 and pHMG95 were introduced into the strain COE2 by electroporation and the transformants were selected on LB agar plates containing $12.5 \mu \mathrm{g} / \mathrm{ml}$ chloramphenicol, $30 \mu \mathrm{g} / \mathrm{ml}$ kanamycin and $50 \mu \mathrm{g} / \mathrm{ml}$ carbenicillin as appropriate. The resulting strains were designated COE3 (COE2/pAES1), COE4 (COE2/pBR322) and COE6 (COE2/pHMG95).

\section{ClyA expression assays}

Lytic activity of the UPEC and K-12 strains were analysed using a double horse blood agar plate. The blood agar plate was supplemented with $2 \mathrm{mM}$ of Sodium-oxalate $\left(\mathrm{Ca}^{2+}\right.$ chelator ). Bacteria were streaked into vertical lines across the plate and $1.5 \mu \mathrm{l}$ of $0.5 \mathrm{mg} / \mathrm{ml}$ of Mitomycin $\mathrm{C}$ was dripped onto the horizontally streaked rows of strains prior to incubation at $37^{\circ} \mathrm{C}$ for maximum 16 hours. Mitomycin $\mathrm{C}$ triggers the bacterial SOS response and hence induces the proliferation of lysogenic phages (Walker, 1996) and thus may cause release of cytolysin A that lyses the blood [9]. 


\section{Immuno-fluroescence assay}

Approximately five bacterial colonies grown on an LB plate overnight were suspended in $100 \mu \mathrm{l}$ water or PBS, and 10 to $20 \mu \mathrm{l}$ of the suspension was placed on a glass slide and air-dried. The cells were fixed with $4 \%$ paraformaldehyde (PFA) in PBS for 10 minutes and wash with PBS. The slides were covered for $20 \mathrm{~min}$ with $0.1 \mathrm{M}$ glycine diluted in PBS, followed by washes in PBS then blocked with 1\% BSA in PBS for 30 min. Polyclonal ClyA antiserum was diluted in a blocking solution and then added to the bacteria on the slide at a final dilution of 1:3,000 and incubated for 2 hours at room temperature or overnight in $4^{\circ} \mathrm{C}$. Alexa Fluor 555 anti-rabbit IgG (Invitrogen) diluted 1:500 in blocking solution was applied to the bacterial cells for 1 hour at room temperature. Washes in $1 \times$ PBS for 15 min were repeated five times and the bacteria were then mounted in a fluorescence mounting medium (Dako). The slides were examined at $1000 \times$ magnification with a Nikon Intensilight C-HGFI system microscope equipped for fluorescence; the images were obtained with a Hamamatsu DRCA-ER camera.

\section{Measurement of luciferase (lux) activity}

Colonies of the bacterial strains MG1655 (K-12), JON53cly $A^{+}:: \operatorname{lu} x A B$ (COE2), COE3, COE4 and COE6, from plates incubated overnight were inoculated into LB broth medium. The bacteria were cultured aerobically at $37^{\circ} \mathrm{C}$. The optical density $\left(\mathrm{OD}_{600 \mathrm{~nm}}\right)$ was measured during growth at different time points. In parallel, the transcriptional activity was measured in a Sirius luminometer using decanal as a substrate. One hundred $\mu \mathrm{l}$ of a $0.1 \% \mathrm{v} / \mathrm{v}$ suspension of decanal (Sigma) in water was added to $100 \mu \mathrm{l}$ of bacterial culture as programmed by the Sirius instrument and light emission was measured. Triplicates were measured for each sample and specific activity (lux activity units/OD $600 \mathrm{~nm}$ ) was calculated and plotted.

\section{Sub-cellular localization of ClyA in K-12 and UPEC derivatives}

Sub-cellular fractionation was performed essentially as explained before [62]. For sub-cellular localization of ClyA, E. coli cells were grown in $\mathrm{LB}$ medium at $37^{\circ} \mathrm{C}$ until late logarithmic phase $\left(\mathrm{OD}_{600 \mathrm{~nm}} \approx 2\right)$. To prepare whole cell lysate fractions, the bacteria $(1 \mathrm{ml})$ were centrifuged at $12,000 \times \mathrm{g}$ for $5 \mathrm{~min}$ and the bacterial pellet was resuspended in $(80 \mathrm{ul}) 20 \mathrm{mM}$ Tris- $\mathrm{HCl}$ pH 8.0 buffer. SDS-polyacrylamide gel electrophoresis (SDS-PAGE) analyses of proteins were performed as described previously [63]. Five $\mu \mathrm{l}$ (from $80 \mu \mathrm{l}$ ) of the bacterial suspensions were loaded in the well. To prepare periplasmic fractions, bacterial suspensions $(1.5 \mathrm{ml})$ with a cell density of approximately $5 \times 10^{9} / \mathrm{ml}$ were harvested by centrifugation. The pellet was washed twice with $10 \mathrm{mM}$ Tris- $\mathrm{HCl}$ ( $\mathrm{pH}$ 8.0) three times and resuspended in $20 \mathrm{mM}$ Tris- $\mathrm{HCl}$ (pH 8.0), 20\% (wt/vol) sucrose, and $0.1 \mathrm{mM}$ EDTA at $25^{\circ} \mathrm{C}$.
After $10 \mathrm{~min}$ the cells were pelleted and resuspended in sterile distilled water. After incubation on ice for $10 \mathrm{~min}$, the cells were removed by centrifugation at $12,000 \times \mathrm{g}$. The supernatant was used as the periplasmic fraction. Periplasmic proteins were concentrated by precipitation with ice-cold 10\% trichloroacetic acid containing $1 \mathrm{mg} / \mathrm{ml}$ deoxycholate. The precipitated proteins were collected by centrifugation at $12,000 \times \mathrm{g}$, washed with acetone, dried under vacuum, and dissolved in sample buffer $(50 \mathrm{mM}$ Tris- $\mathrm{HCl}$ (pH 6.8), 10\% glycerol, 5\% $\beta$-mercaptoethanol, $2 \%$ sodium dodecyl sulfate (SDS), $0.05 \%$ bromophenol blue). Samples were neutralized by addition of saturated Tris solution and boiled for $5 \mathrm{~min}$ at $100^{\circ} \mathrm{C}$.

\section{Western blot analysis}

Western immunoblotting was performed as previously described [64]. The proteins were detected using different primary polyclonal antisera: polyclonal anti-ClyA antiserum [6], and the anti-CRP polyclonal antiserum [62] recognizing E. coli cyclic AMP receptor protein (CRP), which was used as an internal control for cytoplasmic protein and antiserum recognizing TEM- $\beta$ lactamase [62] which was used as the periplasmic protein loading control for strains carrying carbenicillin resistance plasmids. The immunoreactive bands were visualized by scanning using a luminescent image analyzer LAS 4000 IR multi-color (Fujifilm) and/or by exposure on the Hyper film (Amersham Biosciences).

\section{Antimicrobial assays}

MIC determination: Liquid growth inhibition assays were performed essentially as described earlier [53]. Briefly, $\sim 5$ bacterial colonies from an overnight culture plate were suspended in Poor Broth (PB) medium (1\% Bactotryptone, $\mathrm{pH}$ 7.5) or artificial urine media (AUM) and grown aerobically at $37^{\circ} \mathrm{C}$ overnight. Bacterial suspensions were diluted to an $\mathrm{OD}_{600 \mathrm{~nm}}=0.01$ and grown to approximately $\mathrm{OD}_{600 \mathrm{~nm}} 0.2-0.4$ to obtain an exponential phase culture. In a flat-bottom 96-well plate (Falcon), $95 \mu \mathrm{l}$ of the medium was added to all wells, $5 \mu \mathrm{l}$ of the bacterial culture $\left(\mathrm{OD}_{600 \mathrm{~nm}}=0.2\right)$ was added to each well at a final $\mathrm{OD}_{600 \mathrm{~nm}}$ of $0.001\left(1 \times 10^{5}\right.$ cells $\left./ 110 \mu \mathrm{l}\right)$ and a $10 \mu \mathrm{l}$ sample of two-fold serially diluted solutions of the peptide (polymyxin $\mathrm{B}, \beta$-defensin or LL-37) was added to obtain a range from highest $(50 \mu \mathrm{g} / \mathrm{ml})$ to lowest $(0.097 \mu \mathrm{g} / \mathrm{ml})$ concentrations in the series of wells containing bacteria and medium. To determine the effects of some of the components in AUM, media containing higher concentrations of urea (i.e. $340 \mathrm{mM}-680 \mathrm{mM}$ ) and twice the concentration of creatinine (i.e. $14 \mathrm{mM}$ ) were used.

The positive control wells contained only bacteria and medium while the negative control well contained medium and water. The plate was incubated for 16 hours aerobically at $37^{\circ} \mathrm{C}$ in a TECAN Infinite M200 fluorescence multiplate 
reader and bacterial growth was monitored by measuring absorbance at $\mathrm{OD}_{600 \mathrm{~nm}}$ at 5 minute intervals. MIC values are defined as the lowest concentration that causes $100 \%$ growth inhibition. The following Polymyxin B susceptible and resistant organisms were used as controls: $V$. cholerae strain 569B $(\mathrm{MIC}=1.5 \mu \mathrm{g} / \mathrm{ml}), V$. cholerae strain A1552 $(\mathrm{MIC}=50 \mu \mathrm{g} / \mathrm{ml}), \quad$ E. coli strain $\mathrm{MC} 4100 \quad(\mathrm{MIC}=7.8$ $\mu \mathrm{g} / \mathrm{ml})$, E. coli strain MWK11 (MIC = $7.8 \mu \mathrm{g} / \mathrm{ml})$.

\section{Additional files}

Additional file 1: The open access software programs BLAST (http://blast.ncbi.nlm.nih.gov/Blast.cgi) to search for sequences and strains with similarities to the clyA/hlyE gene, and ClustalW (http://pbil.ibcp.fr/htm/index.php) were used for alignment of the sequences with the clyA gene sequences of $E$. coli strain MG1655 (accession number of NC_000913.3) as the reference sequence. It includes the $1.2 \mathrm{~kb}$ region between nucleotide coordinates 1229483 and 1230694 and represents the entire clyA coding sequence and 300 base pairs upstream of the ATG start codon. The sequence of clyA was compared with the corresponding sequences of clyA in other $E$. coli strains (both IPEC and EXPEC). Black nucleotide lettering and dashes indicates position where there are differences in the otherwise red letter compilation. The translational start sequences (ATG and ribosome binding motif) are marked in green. The transcriptional start sequences -35 and -10 motifs and the initiating nucleotide are marked in blue. The binding site for the CRP/FNR regulators is marked in grey. The binding sequences for SlyA are underlined.

Additional file 2: Effect of Polymyxin B on the growth of $E$. coli K-12 derivatives MC4100 and MWK11 in batch cultures of medium AUM at $37^{\circ} \mathrm{C}$

\section{Competing interests}

The authors declare that they have no competing interests.

\section{Authors' contributions}

COAE carried out molecular genetic studies, performed the statistical analysis and participated in the drafting of the manuscript, JO, NZ, MW and MD carried out molecular genetic studies and participated in the drafting of the manuscript. SNW and BEU conceived of the study and participated in its design and coordination and helped to draft the manuscript. All authors read and approved the final manuscript.

\section{Acknowledgements}

The authors wish to thank Katrin Bock and Anders Magnusson for valuable assistance with the initial experiments and Dr. Annika Sjöström for good advice and sharing of materials. This work was supported by grants from the Swedish Research Council to BEU and SNW. JO was supported by a Research Associate Fellowship and research funds from the Faculty of Medicine, Umeå University.

\section{Author details}

${ }^{1}$ Department of Molecular Biology, the Laboratory for Molecular Infection Medicine Sweden (MIMS), Umeå University, S-90187 Umeå, Sweden. ²Present address: Department of Odontology, Oral Microbiology, Umeå University, S-90187 Umeå, Sweden.

Received: 18 December 2013 Accepted: 11 August 2014 Published: 2 September 2014

\section{References}

1. Beutin L: The different hemolysins of Escherichia coli. Med Microbio/ Immunol 1991, 180(4):167-182.

2. del Castillo FJ, Leal SC, Moreno F, del Castillo I: The Escherichia coli K-12 sheA gene encodes a 34-kDa secreted haemolysin. Mol Microbiol 1997, 25(1):107-115
3. Ludwig A, Tengel C, Bauer S, Bubert A, Benz R, Mollenkopf HJ, Goebel W: SlyA, a regulatory protein from Salmonella typhimurium, induces a haemolytic and pore-forming protein in Escherichia coli. Mol Gen Genet 1995, 249(5):474-486.

4. Ludwig A, Bauer S, Benz R, Bergmann B, Goebel W: Analysis of the SlyAcontrolled expression, subcellular localization and pore-forming activity of a $34 \mathrm{kDa}$ haemolysin (ClyA) from Escherichia coli K-12. Mol Microbiol 1999, 31(2):557-567.

5. Oscarsson J, Mizunoe $Y$, Uhlin BE, Haydon DJ: Induction of haemolytic activity in Escherichia coli by the slyA gene product. Mol Microbiol 1996, 20(1):191-199.

6. Oscarsson J, Mizunoe Y, Li L, Lai XH, Wieslander A, Uhlin BE: Molecular analysis of the cytolytic protein ClyA (SheA) from Escherichia coli. Mol Microbiol 1999, 32(6):1226-1238.

7. Wallace AJ, Stillman TJ, Atkins A, Jamieson SJ, Bullough PA, Green J, Artymiuk PJ: E. coli hemolysin E (HlyE, ClyA, SheA): X-ray crystal structure of the toxin and observation of membrane pores by electron microscopy. Cell 2000, 100(2):265-276.

8. Westermark M, Oscarsson J, Mizunoe Y, Urbonaviciene J, Uhlin BE: Silencing and activation of ClyA cytotoxin expression in Escherichia coli. J Bacterio/ 2000, 182(22):6347-6357.

9. Oscarsson J, Westermark M, Beutin L, Uhlin BE: The bacteriophage-associated ehly1 and ehly2 determinants from Escherichia coli $\mathrm{O} 26: \mathrm{H}$ - strains do not encode enterohemolysins per se but cause release of the ClyA cytolysin. Int J Med Microbiol 2002, 291(8):625-631.

10. Reingold J, Starr N, Maurer J, Lee MD: Identification of a new Escherichia coli She haemolysin homolog in avian E. coli. Vet Microbiol 1999, 66(2):125-134.

11. Huang LJ, Cui J, Piao HH, Hong Y, Choy HE, Ryu PY: Molecular cloning and characterization of clyA genes in various serotypes of Salmonella enterica. J Microbiol 2010, 48(5):663-667.

12. Sokurenko EV, Hasty DL, Dykhuizen DE: Pathoadaptive mutations: gene loss and variation in bacterial pathogens. Trends Microbiol 1999, 7(5):191-195.

13. Maurelli AT, Fernandez RE, Bloch CA, Rode CK, Fasano A: "Black holes" and bacterial pathogenicity: a large genomic deletion that enhances the virulence of Shigella spp. and enteroinvasive Escherichia coli. Proc Natl Acad Sci U S A 1998, 95(7):3943-3948.

14. Nakata N, Tobe T, Fukuda I, Suzuki T, Komatsu K, Yoshikawa M, Sasakawa C: The absence of a surface protease, OmpT, determines the intercellular spreading ability of Shigella: the relationship between the ompT and kcpA loci. Mol Microbiol 1993, 9(3):459-468.

15. Sokurenko EV, Chesnokova V, Dykhuizen DE, Ofek I, Wu XR, Krogfelt KA, Struve C, Schembri MA, Hasty DL: Pathogenic adaptation of Escherichia coli by natural variation of the FimH adhesin. Proc Natl Acad Sci U S A 1998, 95(15):8922-8926.

16. Herzer PJ, Inouye S, Inouye M, Whittam TS: Phylogenetic distribution of branched RNA-linked multicopy single-stranded DNA among natural isolates of Escherichia coli. J Bacteriol 1990, 172(11):6175-6181.

17. Bingen E, Picard B, Brahimi N, Mathy S, Desjardins P, Elion J, Denamur E: Phylogenetic analysis of Escherichia coli strains causing neonatal meningitis suggests horizontal gene transfer from a predominant pool of highly virulent B2 group strains. J Infect Dis 1998, 177(3):642-650.

18. Boyd EF, Hartl DL: Chromosomal regions specific to pathogenic isolates of Escherichia coli have a phylogenetically clustered distribution. J Bacteriol 1998, 180(5):1159-1165.

19. Picard B, Garcia JS, Gouriou S, Duriez P, Brahimi N, Bingen E, Elion J, Denamur $E$ : The link between phylogeny and virulence in Escherichia coli extraintestinal infection. Infect Immun 1999, 67(2):546-553.

20. Ochman H, Selander RK: Standard reference strains of Escherichia coli from natural populations. J Bacteriol 1984, 157(2):690-693.

21. Milkman R: Electrophoretic variation in Escherichia coli from natural sources. Science 1973, 182(4116):1024-1026.

22. Oscarsson J: Molecular Analysis of the cytolysin ClyA in Escherichia coli and other Enterobacteria, Umeå University Medical Dissertations. Umeå: Umeå University; 1999

23. Kerenyi M, Allison HE, Batai I, Sonnevend A, Emody L, Plaveczky N, Pal T: Occurrence of hlyA and sheA genes in extraintestinal Escherichia coli strains. J Clin Microbiol 2005, 43(6):2965-2968.

24. von Rhein C, Bauer S, Simon V, Ludwig A: Occurrence and characteristics of the cytolysin A gene in Shigella strains and other members of the family Enterobacteriaceae. FEMS Microbiol Lett 2008, 287(2):143-148. 
25. Murase K, Ooka T, Iguchi A, Ogura Y, Nakayama K, Asadulghani M, Islam MR, Hiyoshi H, Kodama T, Beutin L, Hayashi T: Haemolysin E- and enterohaemolysin-derived haemolytic activity of $055 / 0157$ strains and other Escherichia coli lineages. Microbiology 2012, 158(Pt 3):746-758.

26. Hacker J, Schmidt G, Hughes C, Knapp S, Marget M, Goebel W: Cloning and characterization of genes involved in production of mannose-resistant, neuraminidase-susceptible $(\mathrm{X})$ fimbriae from a uropathogenic O6:K15: H31 Escherichia coli strain. Infect Immun 1985, 47(2):434-440.

27. Hull RA, Gill RE, Hsu P, Minshew BH, Falkow S: Construction and expression of recombinant plasmids encoding type 1 or D-mannose-resistant pili from a urinary tract infection Escherichia coli isolate. Infect Immun 1981, 33(3):933-938

28. van Die I, Bergmans $\mathrm{H}$ : Nucleotide sequence of the gene encoding the F72 fimbrial subunit of a uropathogenic Escherichia coli strain. Gene 1984, 32(1-2):83-90.

29. Tullus K, Horlin K, Svenson SB, Kallenius G: Epidemic outbreaks of acute pyelonephritis caused by nosocomial spread of $\mathrm{P}$ fimbriated Escherichia coli in children. J Infect Dis 1984, 150(5):728-736.

30. Clegg S: Cloning of genes determining the production of mannoseresistant fimbriae in a uropathogenic strain of Escherichia coli belonging to serogroup O6. Infect Immun 1982, 38(2):739-744.

31. Vaisanen-Rhen V, Elo J, Vaisanen E, Siitonen A, Orskov I, Orskov F, Svenson SB, Makela PH, Korhonen TK: P-fimbriated clones among uropathogenic Escherichia coli strains. Infect Immun 1984, 43(1):149-155.

32. Korhonen TK, Valtonen MV, Parkkinen J, Vaisanen-Rhen V, Finne J, Orskov F Orskov I, Svenson SB, Makela PH: Serotypes, hemolysin production, and receptor recognition of Escherichia coli strains associated with neonatal sepsis and meningitis. Infect Immun 1985, 48(2):486-491.

33. Sjostrom AE, Balsalobre C, Emody L, Westerlund-Wikstrom B, Hacker J, Uhlin BE: The SfaXII protein from newborn meningitis $E$. coli is involved in regulation of motility and type 1 fimbriae expression. Microb Pathog 2009, 46(5):243-252.

34. Hanahan D: Studies on transformation of Escherichia coli with plasmids. J Mol Biol 1983, 166(4):557-580.

35. Guyer MS, Reed RR, Steitz JA, Low KB: Identification of a sex-factor-affinity site in E. coli as gamma delta. Cold Spring Harb Symp Quant Biol 1981, 45(Pt 1):135-140.

36. Casadaban MJ, Cohen SN: Analysis of gene control signals by DNA fusion and cloning in Escherichia coli. J Mol Biol 1980, 138(2):179-207.

37. Casadaban MJ: Transposition and fusion of the lac genes to selected promoters in Escherichia coli using bacteriophage lambda and $\mathrm{Mu}$. J Mol Biol 1976, 104(3):541-555.

38. Johansson J, Dagberg B, Richet E, Uhlin BE: H-NS and StpA proteins stimulate expression of the maltose regulon in Escherichia coli. J Bacteriol 1998, 180(23):6117-6125.

39. Wai SN, Lindmark B, Soderblom T, Takade A, Westermark M, Oscarsson J, Jass J, Richter-Dahlfors A, Mizunoe Y, Uhlin BE: Vesicle-mediated export and assembly of pore-forming oligomers of the enterobacterial ClyA cytotoxin. Cell 2003, 115(1):25-35.

40. Simms AN, Mobley HL: Multiple genes repress motility in uropathogenic Escherichia coli constitutively expressing type 1 fimbriae. J Bacterio/ 2008, 190(10):3747-3756.

41. Sjostrom AE, Sonden B, Muller C, Rydstrom A, Dobrindt U, Wai SN, Uhlin BE: Analysis of the sfaX(II) locus in the Escherichia coli meningitis isolate IHE3034 reveals two novel regulatory genes within the promoter-distal region of the main S fimbrial operon. Microb Pathog 2009, 46(3):150-158

42. Paracuellos P, Ohman A, Sauer-Eriksson AE, Uhlin BE: Expression and purification of $S f a X(I I)$, a protein involved in regulating adhesion and motility genes in extraintestinal pathogenic Escherichia coli. Protein Expr Purif 2012, 86(2):127-134

43. Hacker J, Hughes $\mathrm{C}$, Hof H, Goebel W: Cloned hemolysin genes from Escherichia coli that cause urinary tract infection determine different levels of toxicity in mice. Infect Immun 1983, 42(1):57-63.

44. Farabaugh PJ, Schmeissner U, Hofer M, Miller JH: Genetic studies of the lac repressor. VII. On the molecular nature of spontaneous hotspots in the lacl gene of Escherichia coli. J Mol Biol 1978, 126(4):847-857.

45. Albertini AM, Hofer M, Calos MP, Miller JH: On the formation of spontaneous deletions: the importance of short sequence homologies in the generation of large deletions. Cell 1982, 29(2):319-328.
46. Singer BS, Westlye J: Deletion formation in bacteriophage T4. J Mol Biol 1988, 202(2):233-243.

47. Ikeda H, Aoki K, Naito A: Illegitimate recombination mediated in vitro by DNA gyrase of Escherichia coli: structure of recombinant DNA molecules. Proc Natl Acad Sci U S A 1982, 79(12):3724-3728.

48. Uematsu N, Matsuoka C, Agemizu Y, Nagoshi E, Yamamoto K: Asymmetric crossing over in the spontaneous formation of large deletions in the tonB-trp region of the Escherichia coli K-12 chromosome. Mol Gen Genet 1999, 261(3):523-529.

49. Pupo GM, Karaolis DK, Lan R, Reeves PR: Evolutionary relationships among pathogenic and nonpathogenic Escherichia coli strains inferred from multilocus enzyme electrophoresis and mdh sequence studies. Infect Immun 1997, 65(7):2685-2692.

50. Baumler AJ, Tsolis RM, Ficht TA, Adams LG: Evolution of host adaptation in Salmonella enterica. Infect Immun 1998, 66(10):4579-4587.

51. Reynolds AE, Felton J, Wright A: Insertion of DNA activates the cryptic bgl operon in E. coli K12. Nature 1981, 293(5834):625-629.

52. Chromek M, Slamova Z, Bergman P, Kovacs L, Podracka L, Ehren I, Hokfelt T, Gudmundsson GH, Gallo RL, Agerberth B, Brauner A: The antimicrobial peptide cathelicidin protects the urinary tract against invasive bacterial infection. Nat Med 2006, 12(6):636-641.

53. Hetru C, Bulet P: Strategies for the isolation and characterization of antimicrobial peptides of invertebrates. Methods Mol Biol 1997, 78:35-49.

54. Brooks T, Keevil CW: A simple artificial urine for the growth of urinary pathogens. Lett Appl Microbiol 1997, 24(3):203-206.

55. Bolivar F, Rodriguez RL, Greene PJ, Betlach MC, Heyneker HL, Boyer HW, Crosa JH, Falkow S: Construction and characterization of new cloning vehicles. II. A multipurpose cloning system. Gene 1977, 2(2):95-113.

56. Link AJ, Phillips D, Church GM: Methods for generating precise deletions and insertions in the genome of wild-type Escherichia coli: application to open reading frame characterization. J Bacterio/ 1997, 179(20):6228-6237.

57. Xia Y, Gally D, Forsman-Semb K, Uhlin BE: Regulatory cross-talk between adhesin operons in Escherichia coli: inhibition of type 1 fimbriae expression by the PapB protein. EMBO J 2000, 19(7):1450-1457.

58. Brosius J: Superpolylinkers in cloning and expression vectors. DNA 1989, 8(10):759-777

59. Vieira J, Messing J: The pUC plasmids, an M13mp7-derived system for insertion mutagenesis and sequencing with synthetic universal primers. Gene 1982, 19(3):259-268.

60. Yanisch-Perron C, Vieira J, Messing J: Improved M13 phage cloning vectors and host strains: nucleotide sequences of the M13mp18 and pUC19 vectors. Gene 1985, 33(1):103-119.

61. Blattner FR, Plunkett G 3rd, Bloch CA, Perna NT, Burland V, Riley M, ColladoVides J, Glasner JD, Rode CK, Mayhew GF, Gregor J, Davis NW, Kirkpatrick HA, Goeden MA, Rose DJ, Mau B, Shao Y: The complete genome sequence of Escherichia coli K-12. Science 1997, 277(5331):1453-1462.

62. Oscarsson J, Westermark M, Lofdahl S, Olsen B, Palmgren H, Mizunoe Y, Wai $\mathrm{SN}$, Uhlin BE: Characterization of a pore-forming cytotoxin expressed by Salmonella enterica serovars typhi and paratyphi A. Infect Immun 2002, 70(10):5759-5769.

63. Laemmli UK: Cleavage of structural proteins during the assembly of the head of bacteriophage T4. Nature 1970, 227(5259):680-685.

64. Towbin H, Staehelin T, Gordon J: Electrophoretic transfer of proteins from polyacrylamide gels to nitrocellulose sheets: procedure and some applications. Proc Natl Acad Sci U S A 1979, 76(9):4350-4354.

doi:10.1186/s12866-014-0216-4

Cite this article as: Enow et al:: Elevated recombinant clyA gene expression in the uropathogenic Escherichia coli strain 536, a clue to explain pathoadaptive mutations in a subset of extraintestinal $E$. coli strains. BMC Microbiology 2014 14:216. 